\title{
Culture Media Selection for Mass Production of Isaria fumosorosea and Isaria farinosa
}

\author{
Gabriel Moura Mascarin ${ }^{1 *}$, Sérgio Batista Alves $^{1}$ and Rogério Biaggioni Lopes ${ }^{2}$ \\ 'Escola Superior de Agricultura "Luiz de Queiroz"; Universidade de São Paulo; Av. Pádua Dias; C.P.: 9; 13418- \\ 900; Piracicaba - SP - Brasil. ${ }^{2}$ Embrapa Recursos Genéticos e Biotecnologia; Parque Estação Biológica; Av. W5 \\ Norte; 70770-917; Brasília - DF - Brasil
}

\begin{abstract}
This work investigated the production of the fungi Isaria fumosorosea and Isaria farinosa in biphasic fermentation using agro-industrial products and residues. Combinations of natural liquid substrates, alternative to the complete medium and potato dextrose medium, were evaluated. The best liquid media were sugarcane molasses + rice broth, rice broth + yeast and sugarcane molasses + yeast + rice broth, which resulted in the highest viable propagule concentration. The molasses + rice broth medium was selected for the next phase of the study in which the production of both fungal isolates was evaluated in solid grain substrates. In solid-state fermentation, the best conidia production was achieved with the soybean meal and broken corn for I. farinosa, and whole rice and broken rice for I. fumosorosea. Results demonstrated that the two fungal species could be rapidly produced with higher yield of conidia on agro-industrial resources by using biphasic fermentation techniques.
\end{abstract}

Key words: Biphasic fermentation, entomopathogenic fungi, Isaria fumosorosea, Isaria farinosa, agro-industrial products

\section{INTRODUCTION}

In the recent years, studies on mass production of entomopathogenic fungi have demonstrated that the quantity and quality of propagules produced are dependent on several factors, such as the isolates, nutrients, inoculum density and environmental conditions (Leite et al., 2003).

There is a rising commercial demand for bioproducts based on Isaria fumosorosea (Wize) (formerly Paecilomyces fumosoroseus) and Isaria farinosa (Holm: Fr.) Fr. (formerly Paecilomyces farinosus) (Hypocreales: Cordycipitaceae) aiming to control several insect pests, due to the capacity these entomopathogens have to cause natural epizootics (Zimmermann, 2008). The capacity to grow and produce conidia in many carbon and nitrogen sources is one of the factors that make an inexpensive mass production of these fungi possible (Cliquet and Jackson, 1999).

Isaria fumosorosea and Lecanicillium spp. are used in greenhouses in North America and Europe and are increasingly being used in Brazil. These mycoinsecticides are registered for use in greenhouses to control whiteflies, aphids, thrips and scales (Faria and Magalhães, 2001). The capacity of $I$. farinosa to infect Trichoplusia ni, an important pests in soybean was demonstrated by Agudelo and Falcon (1977). In a previous study, Agudelo and Falcon (1983) also observed that its blastospores have great potential for the control of Spodoptera exigua larvae by contact or ingestion.

\footnotetext{
*Author for correspondence: gmmascar@gmail.com
} 
The inundative release is the most commonly used strategy for these pathogens. This strategy requires the production of large quantities of infective propagules.

From this viewpoint, it is necessary to outline the strategies to optimize mass production at competitive prices in order to turn the use of these biocontrol agents feasible. Several nutritional studies have been undertaken to improve the growth and sporulation of filamentous fungi such as Beauveria bassiana, Metarhizium anisopliae and I. fumosorosea (Rombach, 1988; Cruz et al., 1993; Torre and Cardenas-Cota, 1996). Although the production of conidia is mostly based on solidstate fermentation, it requires weeks to complete all process, thereby increasing the production costs. Aerial conidia tend to be more tolerant to desiccation and more stable as a dry preparation, compared to submerged conidia (Jackson, 1997). The liquid fermentation is an alternative to reduce the lead time in the production process of some fungi. Therefore, studies have been carried on the culture media composition using natural and inexpensive ingredients that are commercially available and efficient in a way that the fungus develops and sporulates into a biopesticide (Alvarenga et al., 1988).

Most filamentous fungal entomopathogens employed as biological control agents is produced in a two-stage fermentation, whose first step consists of the production of mycelia or blastospores used as the pathogen inoculum for the second stage. The inoculum is initially produced in liquid culture in shake flasks or fermentors and then transferred onto the solid substrate for conidia production (Jenkins et al., 1998). This technique is named as biphasic fermentation and has been developed as an alternative way to improve the industrial production, resulting in a shorter incubation period, higher conidia productivity and better quality control (Alves and Pereira, 1998).

The LUBILOSA program serves as a reference for the mass production of mycopesticides, once it has developed a biphasic production process of aerial conidia of Metarhizium flavoviridae for the control of grasshoppers in South Africa and West African Sahara (Jenkins et al., 1998). This comprises a suitable technique since it combines the ease and efficiency of a large-scale fungal production and its success in elaboration of a commercial product. Other mycopesticides based on Metarhizium anisopliae, Beauveria bassiana,
Lecanicillium spp., $\quad$ Hirsutella thompsonii and Isaria spp. could also be developed using this technique by utilizing low cost liquid and solid natural substrates, such as agro-industrial products and residues.

There is not much information available on sporulation of I. fumosorosea and I. farinosa related to natural culture media for biphasic fermentation. Therefore, the aim of this study was to select alternative and less costly, liquid and solid substrates for the development of a biphasic production of these two Isaria species.

\section{MATERIAL AND METHODS}

\section{Source of inoculum}

Isaria fumosorosea (ESALQ1296) and I. farinosa (ESALQ1205) were isolated from the host Bemisia tabaci (Genn., 1889) (Hemiptera: Aleyrodidae) and stored in a freezer $\left(-4^{\circ} \mathrm{C}\right)$ in the microbial germplasm of Insect Pathology and Microbial Control Laboratory of Entomology Section at Escola Superior de Agricultura "Luiz de Queiroz" (ESALQ-USP), Piracicaba, Brazil. The inoculum consisted of fungal colony disc of about $1 \mathrm{~cm}$ diameter, cut up using a cork borer after the pure culture had been grown on a complete medium as described in Alves et al. (1998). Thereafter, this colony was incubated for seven days at $26 \pm 0.5^{\circ} \mathrm{C}$ with $12: 12$ (L:D) h photoperiod. The inoculum density of each disc was $3.2 \times 10^{6}$ and $5.7 \times 10^{5}$ conidia.mm $^{-2}$ for the ESALQ1296 and ESALQ1205 isolates, respectively.

\section{Phase I: Liquid fermentation}

In this phase, the fungi were produced by submerged fermentation using different liquid culture media. Seven treatments for each fungus were used through a combination of fungal isolates and liquid culture media. The three main ingredients used at different combinations were rice broth, molasses and dry yeast extract. Besides complete medium (CM) and potato-dextrose (PD) that were used as standards, other natural and alternative culture media included sugarcane molasses (M), molasses + yeast (MY), molasses + rice broth (MR), rice broth + yeast $(\mathrm{RY})$, molasses + yeast + rice broth (alternative complete medium, MYR). All these media contained nitrogen and carbon sources, essential for fungal production, except for molasses (Table 1). 
Table 1 - Composition of liquid media used in submerged fermentation of two Isaria species.

\begin{tabular}{lccccc}
\hline \multirow{2}{*}{ Liquid medium } & \multicolumn{3}{c}{${\text { Ingredient }\left(\mathbf{g . L}^{\mathbf{- 1}} \text { ) }\right.}$} \\
\cline { 2 - 6 } Complete medium (MC) & Dextrose & Molasses & Potato $^{2}$ & Rice $^{2}$ & Yeast \\
Potato-Dextrose (PD) & 10.0 & - & - & - & 5.0 \\
Molasses 3\% (M) & 15.0 & - & 200.0 & - & - \\
Molasses-Yeast (MY) & - & 30.0 & - & - & - \\
Molasses-Rice (MR) & - & 30.0 & - & - & 5.0 \\
Rice-Yeast (RY) & - & 30.0 & - & 200.0 & - \\
Molasses-Yeast-Rice (MYR) & - & - & - & 200.0 & 5.0 \\
\hline
\end{tabular}

${ }^{1}$ Additional minerals: $0.36 \mathrm{~g} \mathrm{KH}_{2} \mathrm{PO}_{4}, 1.05 \mathrm{~g} \mathrm{NaHPO}_{4} \cdot 7 \mathrm{H}_{2} \mathrm{O}, 0.6 \mathrm{~g} \mathrm{MgSO} \cdot 7 \mathrm{H}_{2} \mathrm{O}, 1.0 \mathrm{~g} \mathrm{KCl}$ and $1.58 \mathrm{~g} \mathrm{NaNO}_{3} .{ }^{2} \mathrm{Rice}$ and potato tubers were cooked in distilled water to achieve their respective broth, which was used in the medium.

One liter of each liquid medium was prepared and placed into eight Erlenmeyer flasks separated in four replicates for each fungal isolate. The flasks were cotton-puggled and autoclaved at $120^{\circ} \mathrm{C}$ for $20 \mathrm{~min}$. Fifty milligram of the antibiotic tetracycline was then added into each flask and inoculated with one colony disc of each fungus containing $2.5 \times 10^{8}$ and $4.5 \times 10^{7}$ conidia for ESALQ1296 and ESALQ1205, respectively. The flasks were fixed to a rotary shaker $(220 \mathrm{rpm})$ at $27 \pm 0.5^{\circ} \mathrm{C}$ in total darkness for four days. The parameters were evaluated sequentially and chronologically at different times of shaking. All the media containing molasses were autoclaved twice in $12 \mathrm{~h}$ of interval, aiming to ensure their sterilization.

After $24 \mathrm{~h}$ of incubation, aliquots of $1 \mathrm{~mL}$ of each replicate were transferred into sterile glass tubes containing $9 \mathrm{~mL}$ distilled water $\left(\mathrm{dH}_{2} \mathrm{O}\right)$ and the surfactant (Tween $45^{\circledR}-0.01 \%$ ). The fungal suspension was diluted successively and vortexed until obtain a desirable dilution $\left(10^{-3}\right.$ or $\left.10^{-4} \mathrm{~mL}\right)$ for each treatment. The quantity of $0.1 \mathrm{~mL}$ of this final suspension was pipetted onto Petri dishes containing potato dextrose agar-based solid medium (PDA: $15 \mathrm{~g}$ agar, $15 \mathrm{~g}$ dextrose, $200 \mathrm{~g}$ potato tubers in $1 \mathrm{~L} \mathrm{dH}_{2} \mathrm{O}$ ) and spread using a Drigalsky spatula. Two plates of each replicate were inoculated and incubated at $26 \pm 0.5^{\circ} \mathrm{C}$ in 12:12 (L:D) $\mathrm{h}$ photoperiod. After 5-6 days of incubation, the number of colony forming units (CFU) was determined for both Isaria species, and for contaminant fungi and bacteria, in order to determine the proportion of the propagule yield and contaminants. The contaminant fungi and bacteria were determined by the following equation: Contamination $(\%)=$ (number of contaminant CFU/number of total CFU) $\times 100$.

After a $30 \mathrm{~h}$ of incubation period, one milliliter of fungal suspension was collected and distributed into sterile glass tubes. The same procedure of successive dilutions was performed here, so that the conidia were counted under a phase-contrast microscope with Neubauer chamber (400x magnification). A mean of four scores represented each replicate per treatment. The observed propagules were blastospores, two-septate hyphae (bipolar) and submerged conidia (microcyclic sporulation). Since the propagules of both fungal isolates were similar in liquid medium, a propagule size range for counting was established: $3 \mu \mathrm{m}$ in width and 8-126 $\mu \mathrm{m}$ in length.

After a four-day incubation period, the liquid content of each flask (98 mL) was removed through $14.5 \mathrm{~cm}$-diameter filter-paper by vacuum filtration in a Buchner funnel. The mycelial mass was air-dried in laminar flow chamber at $26 \pm 0.5^{\circ} \mathrm{C}$ for $2-3 \mathrm{~h}$ until reach the constant weight. The dry weight of biomass was expressed in g.flask ${ }^{-1}$.

\section{Phase II: Solid-state fermentation}

The solid media were prepared from the standard medium (whole rice - WR) and other alternative substrates, including broken rice (BR), milled rice (MR), broken corn (BC), soybean meal (SM), rice husk (RH), wheat grain (WG) and sugarcane bagasse $(\mathrm{SB})$. Whole rice consisted of grains (7 $\mathrm{mm}$ long $\times 2 \mathrm{~mm}$ thick) cooked for 8-10 $\mathrm{min}$ in order to obtain a highly elastic consistency. Broken grain by-product from rice industrial processing (BR: $3 \mathrm{~mm}$ long $\times 2 \mathrm{~mm}$ thick) was submerged in water for $40 \mathrm{~min}$. Rice was milled (MR) in a blender for $15 \mathrm{~s}$, producing a smaller size than the broken rice $(1.88 \mathrm{~mm}$ long $\times 1.75$ $\mathrm{mm}$ thick). From each $100 \mathrm{~g}$ rice, $80 \mathrm{~g}$ milled rice was produced. After milling, the rice was submerged in water for $40 \mathrm{~min}$. Broken grain byproduct from corn industrially processed corn (BC) was submerged in water for $60 \mathrm{~min}$. Wheat whole grains (WG) were cooked for ten minutes in 
water. The rice husk $(\mathrm{RH})$ was extracted from the rice industrially processed and it was submerged in water for one minute. The soybean meal (SM) derived from the industrially processed soybean and it was submerged in water for $30 \mathrm{~s}$. Pieces of sugar cane milled (SB: 4-8 cm) were submerged in water for one minute. In this phase, tray method adapted from Alves and Pereira (1989) was used to produce fungi in solid-state fermentation.

Polypropylene bags were filled with $300 \mathrm{~g}$ of each solid substrate, sealed and autoclaved at $120^{\circ} \mathrm{C}$ for $20 \mathrm{~min}$. In order to allow the space and oxygen for fungal growth, bags were half-filled with the substrate. Once cooled, the bags were transferred to an aseptic laminar flow chamber. The bags were opened and inoculated with $10 \mathrm{~mL}$ of fermented broth from the MR medium, previously fermented for $30 \mathrm{~h}$ and selected from the first phase for both fungal isolates. The bags were closed and vigorously manually shaken for uniform distribution of the propagules in the substrate, and then stored in an incubation chamber at $26 \pm 0.5^{\circ} \mathrm{C}$ with $12: 12$ (L:D) h photoperiod. On the $4^{\text {th }}$ day, bags were drilled using a sterile needle $\left(50\right.$ holes.bag $\left.{ }^{-1}\right)$ to allow the aeration and fungal sporulation. After seven days, bags that showed uniform mycelial growth and sporulation were selected, and the ones that showed contamination were discarded. The noncontaminated bags were opened and their content was spread onto previously disinfected plastic trays $(30 \times 45 \times 12.5 \mathrm{~cm})$. The total content of the bags was distributed into four trays per treatment. The trays were piled on top of each other in a way to allow aeration and drying in an aseptic room with vertical laminar air flow at $29 \pm 1^{\circ} \mathrm{C}$ in total darkness. A dehumidifier was used to accelerate the drying process in four days.

For the RH substrate, at least $200 \mathrm{~g}$ were put into each bag, since $300 \mathrm{~g}$ of this substrate would fill more than one-third of the volume of the bag. This substrate was autoclaved twice in a row.

After the drying process, some parameters were evaluated. Four samples of $10 \mathrm{~g}$ of the funguscolonized substrate were collected from the trays of each treatment. These samples were diluted into Erlenmeyer flasks containing $100 \mathrm{~mL} \mathrm{dH}_{2} \mathrm{O}+$ $0.01 \%$ Tween $45^{\circledR}$. The samples were successively diluted and, then, the number of conidia. ${ }^{-1}$ of solid substrate was quantified for each replicate using a Neubauer chamber (400x magnification).
For germination study, one gram of the funguscolonized substrate was suspended in $10 \mathrm{~mL} \mathrm{dH}_{2} \mathrm{O}$ $+0.01 \%$ Tween $45^{\circledR}$, and $10 \mu \mathrm{L}$ droplet of this suspension was inoculated onto Petri dishes containing PDA. After $24 \mathrm{~h}$ incubation at $26 \pm 0.5^{\circ} \mathrm{C}$ in $12: 12$ (L:D) $\mathrm{h}$ photoperiod, the proportion of conidia that had germinated was determined by observation through a phasecontrast microscope (400x magnification). The sample size was 300 conidia per plate. Each treatment had four replicates. For assessing the contamination, after successively dilutions of the original fungal suspensions to $10^{-3}$ or $10^{-4} \mathrm{~mL}$, four plates (replicates) per treatment were inoculated with $0.1 \mathrm{~mL}$ conidial suspension onto PDA medium and incubated for four days in the same abovementioned conditions. After the incubation period, the percentage of contaminant fungi and bacteria was recorded by the proportion between number of contaminant CFU and total number of CFU. The conidia yield was determined by the relationship between dry-harvested conidia and dry fungus-colonized substrate $(\mathrm{w} / \mathrm{w})$. Initially, after the drying process, the material in the trays was weighed. After that, aerial conidia were harvested by manually shaking the funguscolonized substrate through a 35 -mesh sieve (279 $\mu \mathrm{m}$ pore size) and weighed again. The sieving procedure took $5 \mathrm{~min}$ for each replicate, consisting of four replicates per treatment.

\section{Statistical analysis}

Statistical analysis of different parameters of the liquid and solid-state fermentation studies followed a completely randomized design in a $2 \times 7$ and $2 \times 8$ factorial schemes, respectively. Data of number of CFU, concentration of propagules, dry mycelial weight, conidia production and conidia yield were analyzed through two-way analysis of variance (two-way ANOVA) using a generalized linear model (PROC GLM). Means were compared by the TukeyKramer HSD test and considered to be statistically different at the 5\% significance level. Data on CFU number, propagules concentration and conidia production were subjected to logarithmic transformation $\left[\log _{10}(\mathrm{x})\right]$ to improve homogeneity of variances and to be normalized before the data analysis. All data analyses were performed using the SAS 8.02 software (SAS Institute, 2001). 


\section{RESULTS AND DISCUSSION}

The alternative liquid culture media were composed of inexpensive and largely available agro-industrial by-products. The three main ingredients used, in different combinations, were rice broth, molasses and dry yeast extract. Similarly to the molasses and yeast extract, which are by-products from sugar industry, the rice broth means an important residue from mycopesticide biofactories due to its large volume produced by the solid-state fermentation method.

The CM medium had the maximum influence on the CFU number for ESALQ1296 $(p<0.0001)$. The mean propagules concentration and the dry mycelial weight of ESALQ1296 were better on CM, RY, MR, and MYR ( $p=0.0001)$. The fungus ESALQ1205 showed the highest CFU number in
MR, RY and MYR, highest concentration of propagules in RY and MYR and highest dry mycelial weight in MR and MYR $(p=0.0001)$. It was noted that the simplest media, such as PD, M and MY, yielded lower concentration of propagules for ESALQ1296 than when fermented in CM. On the other hand, ESALQ1205 produced higher amount of propagules when grown on MR, RY and MYR than on PD, M and MY. The MR medium promoted better development for both the isolates than $\mathrm{CM}$ and $\mathrm{PD}$, except for CFU number and dry biomass of ESALQ1296 produced in CM. These results suggested that the presence of rice broth in the media (MR, RY and MYR) generated higher concentration of propagules and dry biomass than the other alternative media ( $\mathrm{M}$ and MY) for these fungal isolates (Table 2).

Table 2 - Number of colony forming units (CFU), concentration of propagules and dry mycelial weight of Isaria fumosorosea (ESALQ1296) and Isaria farinosa (ESALQ1205) for different liquid substrates.

\begin{tabular}{|c|c|c|c|c|c|c|}
\hline \multirow{2}{*}{$\begin{array}{l}\text { Liquid } \\
\text { medium }^{3}\end{array}$} & \multicolumn{2}{|c|}{$\begin{array}{l}\text { Number of colonies } \\
\left(10^{4} \text { CFU.mL }\right. \\
\left.\text { C }^{-1}\right)^{1}\end{array}$} & \multicolumn{2}{|c|}{$\begin{array}{c}\text { Concentration } \\
\left(\mathbf{1 0}^{4} \text { propagules.mL }{ }^{-1}\right)^{1}\end{array}$} & \multicolumn{2}{|c|}{$\begin{array}{l}\text { Dry mycelial weight } \\
\quad\left(\text { g.flask }^{-1}\right)^{2,4}\end{array}$} \\
\hline & ESALQ1296 & ESALQ1205 & ESALQ1296 & ESALQ1205 & ESALQ1296 & ESALQ1205 \\
\hline $\mathrm{CM}$ & $\begin{array}{c}370.00 \pm 157.10 \\
\mathrm{Aa}\end{array}$ & $\begin{array}{c}2.15 \pm 0.79 \\
\mathrm{BCb}\end{array}$ & $\begin{array}{c}290.63 \pm 32.92 \\
\text { Аa }\end{array}$ & $\begin{array}{c}105.94 \pm 53.31 \\
\mathrm{BCa}\end{array}$ & $0.78 \pm 0.06 \mathrm{ABa}$ & $0.57 \pm 0.10 \mathrm{BCa}$ \\
\hline PD & $\begin{array}{c}12.5 \pm 4.10 \\
\mathrm{Ba}\end{array}$ & $0.81 \pm 0.33 \mathrm{Cb}$ & $\begin{array}{c}3.75 \pm 0.44 \\
\mathrm{Bb}\end{array}$ & $\begin{array}{c}42.03 \pm 21.70 \\
\mathrm{CDa}\end{array}$ & $0.44 \pm 0.01 \mathrm{Da}$ & $0.42 \pm 0.01 \mathrm{DEa}$ \\
\hline M & $\begin{array}{c}1.23 \pm 0.20 \\
\mathrm{Ca}\end{array}$ & $\begin{array}{c}2.08 \pm 0.99 \\
\mathrm{BCa}\end{array}$ & $\begin{array}{c}0.81 \pm 0.35 \\
\mathrm{Cb}\end{array}$ & $\begin{array}{c}8.44 \pm 3.02 \\
\mathrm{Da}\end{array}$ & $\begin{array}{c}0.15 \pm 0.01 \\
\mathrm{Ea}\end{array}$ & $\begin{array}{l}0.25 \pm 0.02 \\
\mathrm{Ea}\end{array}$ \\
\hline MY & $2.35 \pm 0.36 \mathrm{BCa}$ & $\begin{array}{c}1.18 \pm 0.40 \\
\mathrm{BCa}\end{array}$ & $\begin{array}{c}6.09 \pm 2.95 \\
\mathrm{Ba}\end{array}$ & $\begin{array}{c}32.81 \pm 9.09 \\
\mathrm{Ca}\end{array}$ & $0.56 \pm 0.03 \mathrm{CDa}$ & $0.54 \pm 0.06 \mathrm{CDa}$ \\
\hline MR & $12.00 \pm 2.71 \mathrm{Ba}$ & $\begin{array}{c}53.80 \pm 26.99 \\
\text { Aa }\end{array}$ & $\begin{array}{c}164.22 \pm 22.90 \\
\mathrm{Aa}\end{array}$ & $\begin{array}{c}250.31 \pm 23.50 \\
\mathrm{Ba}\end{array}$ & $0.65 \pm 0.03 \mathrm{BCa}$ & $0.94 \pm 0.02 \mathrm{Aa}$ \\
\hline RY & $4.75 \pm 0.43 \mathrm{BCb}$ & $\begin{array}{c}47.00 \pm 12.15 \\
\mathrm{Aa}\end{array}$ & $\begin{array}{c}284.38 \pm 83.60 \\
\mathrm{Ab}\end{array}$ & $\begin{array}{c}1921.94 \pm 174.42 \\
\text { Аa }\end{array}$ & $0.74 \pm 0.01 \mathrm{Aa}$ & $0.59 \pm 0.01 \mathrm{CDa}$ \\
\hline MYR & $5.06 \pm 1.20 \mathrm{BCa}$ & $\begin{array}{c}6.88 \pm 5.25 \\
\mathrm{ABa}\end{array}$ & $78.13 \pm 28.13 \mathrm{Aa}$ & $\begin{array}{c}609.38 \pm 238.27 \\
\mathrm{ABa}\end{array}$ & $0.91 \pm 0.05 \mathrm{Aa}$ & $0.83 \pm 0.05 \mathrm{ABa}$ \\
\hline $\mathrm{CV}(\%)^{5}$ & 7 & & & & & \\
\hline
\end{tabular}

${ }^{1}$ Letters obtained from $\log _{10}(\mathrm{x})$ transformed data. ${ }^{2}$ Letters obtained from untransformed data. Means $( \pm$ standard error, SE) followed by the same upper case letters (within the columns) and lower case letters (within the rows) do not differ significantly by Tukey-Kramer HSD test $(\alpha=0.05)$. ${ }^{3}$ Liquid medium composition: $\mathrm{CM}=$ complete medium, $\mathrm{PD}=$ potato-dextrose, $\mathrm{M}=$ molasses, $\mathrm{MY}=$ molasses+yeast, $\mathrm{MR}=$ molasses+rice, $\mathrm{RY}=$ rice+yeast, $\mathrm{MYR}=$ molasses+yeast+rice. ${ }^{4}$ Flask's content was 98 $\mathrm{mL} .{ }^{5}$ Coefficient of variation. Untransformed data are presented.

The MR medium indeed favored the both tested fungi for all evaluated parameters. In addition, this medium seems to be more practical and less costly than the others, because their ingredients can be obtained from the sugarcane industrial process and from the solid-state fermentation of rice at mycopesticide biofactories. Moreover, the use of rice broth in fungal liquid fermentation, instead of discarding it, could solve this issue regarding the disposal of this residue. The MR medium was selected for the second phase of the biphasic fermentation system. The medium $\mathrm{M}$ was 
considered non-viable for the liquid fermentation of the fungi probably due to its unsuitable $\mathrm{C} / \mathrm{N}$ ratio.

Similar study with I. fumosorosea was carried out by Rayati et al. (2001) who reported that the maximum biomass production could be achieved at $36 \mathrm{~h}$ submerged fermentation at $14 \mathrm{C} / \mathrm{N}$ ratio, containing nitrogen and carbon organic sources. The conidia concentration in PD after $30 \mathrm{~h}$ of fermentation to ESALQ1205 was similar to the mean yield of I. farinosa blastospores from 2,500 $\mathrm{mL}$ peptone-dextrose liquid medium after four days of culture, which was $4.6 \times 10^{5} \mathrm{~mL}^{-1}$ (Agudelo and Falcon, 1983). Humphreys et al. (1990) showed that the sporulation of I. farinosa in submerged culture decreased when poor carbon sources were used or under limited amount of nitrogen, as observed here for the molasses medium. In another studies, the bean broth medium promoted the highest submerged conidia production for $M$. anisopliae and $B$. bassiana (Cruz et al., 1993; Batista Filho et al., 1985). Besides, these authors selected that medium based on its low cost and easiness to be prepared.

During liquid fermentation, the media achieved viscous consistency due to fungal growth, and the color of the media also differed for each isolate ranging from light cream to the yellow color when they were grown with ESALQ1296, whereas the dark-violet color was characteristic of ESALQ1205. Color changes and medium consistency could be related to the intense growth of fungal mycelia, nutrient metabolism and production of several metabolites. Furthermore, after $24 \mathrm{~h}$ of fermentation, all media presented mycelial pellet formation for both fungi, increasing their sizes until the last $94 \mathrm{~h}$. The presence of mycelial pellets in liquid fermentation has already been observed for I. farinosa and $I$. fumosorosea previously (Humphreys et al., 1990; Torre and Cardenas-Cota, 1996).

The maximum production of dry biomass for $I$. fumosorosea obtained by Torre and CardenasCota, (1996) was $7.5 \mathrm{mg} \cdot \mathrm{mL}^{-1}$ in submerged culture after four days at $37^{\circ} \mathrm{C}$ with $12: 12$ (L:D) h photoperiod. Conversely, the highest biomass production obtained for I. fumosorosea and $I$. farinosa were $9.29 \mathrm{mg} . \mathrm{mL}^{-1}$ in MYR and 9.59 mg. $\mathrm{mL}^{-1}$ in MR, respectively, after four days of fermentation at $26^{\circ} \mathrm{C}$ with the same photoperiod regime (Table 2 ).

The production of mycelial biomass is a suitable measure to be used when it is need high quantity of dry mycelium for further formulation, with emphasis on its field application. It is also a good parameter to be used for assessing growth and nutritional behavior of the fungi in liquid media. However, this is not reflected in the biphasic production efficiency. Some important aspects should be avoided during the inoculation of the solid medium, such as the longer time of incubation that produces huge amounts of mycelium. It was observed that, after four days of liquid fermentation, many big spherical shaped mycelial pellets were formed, which decreased the number of colonization points in the solid medium and, consequently, delayed the fungal colonization over the solid substrate. According to Jenkins et al. (1998), these pellets are not favorable for use in the inoculation of solid substrates, because they do not allow total coverage of the substrate particles. The longer the solid substrate is exposed without fungal colonization, the higher is the chance of contamination. Thus, a medium which promotes high concentration of propagules in a shorter period of time must be chosen for inoculation of the solid medium. Suitable liquid media could be selected based on CFU number and propagules concentration, because a higher number of viable propagules promotes a quicker colonization of the solid medium.

After $30 \mathrm{~h}$ of submerged fermentation, we obtained a high number of viable blastospores and this type of propagules colonizes the substrate rapidly due to a faster germination rate than aerial conidia. Jackson et al. (2003) observed more than $90 \%$ blastospores of I. fumosorosea after $6 \mathrm{~h}$ of incubation, while conidia required $16 \mathrm{~h}$ of incubation to achieve this germination rate.

The solid substrates which resulted in the highest conidia productions were BC and SM for ESALQ1205 and WR for ESALQ1296 $(p<0.0001)$. The mean values were $1.3 \times 10^{9}, 1 \times$ $10^{9}$ and $1.1 \times 10^{9}$ conidia. $^{-1}$, respectively. The media WG and RH presented low conidia concentration and yield for both the pathogens, probably because $\mathrm{C} / \mathrm{N}$ ratio and nutritional requirements were not appropriated for these fungi (Table 3). Other factors such as particle size (aeration) and grain moisture may have affected the fungal growth and sporulation.

Tanzini (2002) tested two production methods, in trays and boxes, and noticed that I. fumosorosea produced $70 \%$ more in the box method than in the tray one. In the former method, it was $15 \%$ more productive than $B$. bassiana. In the tray method, $B$. 
bassiana was the most productive fungus, whereas I. fumosorosea and $M$. anisopliae were the least productive ones. In this case, the box method provided a better environment of moisture and aeration for the I. fumosorosea growth, which could account for its higher conidia production. After the submerged fermentation of $I$. fumosorosea, Rayati et al. (2001) obtained $4.5 \times$ $10^{9}$ spores. $\mathrm{g}^{-1}$ biomass by stationary phase nutrient condition (surface system for sporulation) over $120 \mathrm{~h}$. This result was 4-times higher than the conidia production achieved by the best solid media for ESALQ1296 and ESALQ1205. Another study using agro-industrial residues revealed that the proportion of $60 \%$ potato refuse and $40 \%$ sugarcane bagasse promoted high production of aerial conidia of B. bassiana $\left(3.4 \times 10^{9}\right.$ conidia. $^{-1}$ dry mass) in Erlenmeyer flasks (Santa et al., 2005), demonstrating the feasibility of these byproducts as alternative nutritional sources to produce entomopathogenic fungi.

Table 3 - Conidia production and yield of Isaria fumosorosea (ESALQ1296) and Isaria farinosa (ESALQ1205) for different solid substrates.

\begin{tabular}{|c|c|c|c|c|}
\hline \multirow{2}{*}{ Solid medium ${ }^{3}$} & \multicolumn{2}{|c|}{ Conidia production $\left(10^{7} \text { conidia.g }^{-1}\right)^{1}$} & \multicolumn{2}{|c|}{ Conidia yield $(\%)^{2}$} \\
\hline & Esalq-1296 & Esalq-1205 & Esalq-1296 & Esalq-1205 \\
\hline WR & $114.06 \pm 19.11 \mathrm{Ab}$ & $11.44 \pm 3.22 \mathrm{DEa}$ & $2.15 \pm 0.13 \mathrm{Ab}$ & $1.24 \pm 0.07 \mathrm{BCa}$ \\
\hline BR & $57.97 \pm 4.69 \mathrm{Ba}$ & $50.06 \pm 6.98 \mathrm{ABa}$ & $1.07 \pm 0.05 \mathrm{Bb}$ & $1.72 \pm 0.06 \mathrm{Aa}$ \\
\hline MR & $43.53 \pm 2.41 \mathrm{Ba}$ & $25.47 \pm 2.77 \mathrm{BCa}$ & $0.53 \pm 0.04 \mathrm{Ca}$ & $0.95 \pm 0.09 \mathrm{CDa}$ \\
\hline $\mathrm{BC}$ & $18.25 \pm 2.97 \mathrm{Cb}$ & $105.75 \pm 11.92 \mathrm{Aa}$ & $0.53 \pm 0.08 \mathrm{Cb}$ & $1.56 \pm 0.13 \mathrm{ABa}$ \\
\hline WG & $7.04 \pm 0.57 \mathrm{Da}$ & $7.71 \pm 0.34 \mathrm{Ea}$ & $0.17 \pm 0.05 \mathrm{Ca}$ & $0.08 \pm 0.04 \mathrm{Ea}$ \\
\hline RH & $6.38 \pm 0.89 \mathrm{Db}$ & $14.31 \pm 1.37 \mathrm{CDEa}$ & $0.48 \pm 0.11 \mathrm{Ca}$ & $0.08 \pm 0.02 \mathrm{Ea}$ \\
\hline SM & $33.72 \pm 4.80 \mathrm{BCb}$ & $132.90 \pm 10.11 \mathrm{Aa}$ & $1.82 \pm 0.12 \mathrm{Ab}$ & $0.71 \pm 0.10 \mathrm{Da}$ \\
\hline SB & $18.94 \pm 0.77 \mathrm{Ca}$ & $17.90 \pm 3.68 \mathrm{CDa}$ & $0.41 \pm 0.05 \mathrm{Ca}$ & $0.08 \pm 0.03 \mathrm{Ea}$ \\
\hline
\end{tabular}

${ }^{\mathrm{T}}$ Letters obtained from $\log _{10}(\mathrm{x})$ transformed data. ${ }^{2}$ Letters obtained from untransformed data. Means $( \pm$ SE) followed by the same upper case letters (within the columns) and lower case letters (within the rows) do not differ significantly by Tukey-Kramer HSD test $(\alpha=0.05) .{ }^{3}$ Solid medium composition: $\mathrm{WR}=$ whole rice, $\mathrm{BR}=$ broken rice, $\mathrm{MR}=$ milled rice, $\mathrm{BC}=$ broken corn, $\mathrm{WG}$ $=$ wheat grain, $\mathrm{RH}=$ rice husk, $\mathrm{SM}=$ soybean meal, $\mathrm{SB}=$ sugarcane bagasse. ${ }^{4}$ Coefficient of variation. Untransformed data are presented.

In this work, the WR substrate promoted the highest conidia yield for ESALQ1296 as well as $\mathrm{BR}$ and BC media for ESALQ1205 $(p<0.0001)$ (Table 3). The final moisture, after the drying, varied according to the solid substrates and, subsequently, affected the spore extraction. The final moisture of each substrate was not measured, but it was observed for whole rice that the moisture decreased to 7-9\% using this drying method. There was an abundant mycelial growth for WG but low sporulation, and for RH, poor mycelial growth was observed. For the other substrates, especially WR, BR and BC, the fungal sporulation occurred all over the grains. The conidial viability of both the isolates was $100 \%$ for all the solid media tested.

As for M. anisopliae, Alves and Pereira (1989) obtained between 6 and $11.4 \%$ of the product yield with $10^{10}$ conidia.g $^{-1}$. This yield could be considered good in comparison to the traditional production process in bottles, which could achieve up to $12 \%$. On industrial scale, $9 \%$ is the average yield for production of this fungus using the tray method (Alves and Pereira, 1998). It was observed that the conidia yield, as well as its concentration, might vary according to the method used in the solid fermentation, incubation time, grain size (aeration), substrate moisture and nutritional composition, the fungal species and also their isolates tested.

For the biphasic production of Isaria species, the duration of the liquid fermentation lasted $30 \mathrm{~h}$ and solid-state fermentation, just 11 days. The drying process remains a constraint for solid-state fermentation, because it is a slow and expensive stage. However, improved drying methods have 
been developed to be used in microbial producing companies that provide a short drying time.

The dose of $0.5 \mathrm{mg} \cdot \mathrm{mL}^{-1}$ of tetracycline resulted in low level of contamination in the liquid media, maximum of $6.25 \%$ for MYR + ESALQ1205, and it had no detrimental effect on the fungal development. In relation to the solid substrate purity, the highest contamination levels occurred for SB + ESALQ1205 and SB + ESALQ1296, in which mean values were about 1.3 and $3.5 \%$, respectively (data not shown). The main contaminants were bacteria. Alves and Pereira (1989) found contamination levels within this range, between 2 and $10 \%$ in the $M$. anisopliae production and about $1 \%$ for $B$. bassiana produced on rice. According to Leite et al. (2003), the fungi can be used if they present less than $10 \%$ contamination.

An important key to use these liquid and solid substrates for fungal production is to determine their chemical composition and $\mathrm{C} / \mathrm{N}$ ratio, because they are products or residues with vegetal origin and their nutrients are considerably variable and depend on the plant species and varieties, harvest times, farms and plots. This variation may greatly affect the fungal production parameters as there are no standard substrates in the market. However, analysis on nutrients for the different substrates, aiming to control these variations, is recommended to assure the quality of the substrates. Another suggestion has been proposed by Jenkins et al. (1998) that the best option would be to select the substrate that could offer consistent results when repeating the experiment several times.

The apparent disparity of the results found in published reports may be due to the different methodologies employed in the studies, making it difficult to establish comparisons with our data.

Based on these results, it was deduced that there was no common substrate for both isolates tested that could give reliable results for solid-state fermentation. Nevertheless, the WR medium was the best for ESALQ1296, whereas SM presented the best conidia production for ESALQ1205. In this range of substrates tested, some could be used for large scale production of these fungi (BR and BC for ESALQ1205 and BR for ESALQ1296). Some natural culture media used in this study demonstrated potential to be employed in a biphasic fermentation system for these two entomopathogens targeting a large-scale production as mycoinsecticides.

\section{CONCLUSIONS}

The short time of liquid fermentation for the production of viable propagules of these two species of Isaria could be a major economic advantage, because it translated into faster colonization of solid substrates and reduced solidstate fermentation time. The variation in the production of viable propagules using the liquid fermentation, and in the conidia production and yield using the solid-state fermentation depended on the Isaria specie, and the nutritional composition of the culture medium. Therefore, the biphasic production of ESALQ1205 could be achieved with MR, RY or MYR liquid media and with SM, WR or BR solid media. The biphasic production of ESALQ1296 could be achieved with MR, RY or MYR liquid media and with WR or BR solid media.

\section{ACKNOWLEDGEMENTS}

We are grateful to The State of São Paulo Research Foundation (FAPESP) for supporting this research and for the scholarship to the first author. We express our sincere appreciation to Ítalo Delalibera Jr. (Ph.D., University of São Paulo) and Vitalis Wafula Wekesa (Ph.D., University of São Paulo) for reviewing this paper and for their valuable technical advices.

\section{RESUMO}

Estudou-se a produção dos fungos Isaria fumosorosea (ESALQ1296) e Isaria farinosa (ESALQ1205) em fermentação líquida e sólida utilizando produtos e resíduos agroindustriais. Inicialmente, avaliaram-se combinações de substratos líquidos naturais e alternativos aos meios completo e batata-dextrose. Os meios líquidos mais promissores foram: melaço + caldo de arroz, caldo de arroz + levedura e melaço + levedura + caldo de arroz, pois resultaram nas maiores produções de propágulos viáveis. $\mathrm{O}$ meio melaço + caldo de arroz foi selecionado para etapa seguinte do trabalho, na qual se avaliou a produção dos fungos em grãos. A fermentação sólida foi mais eficiente quando se utilizaram os meios de farelo de soja e milho quirela para I. farinosa, e arroz inteiro e arroz quirela para I. fumosorosea. A 
fermentação bifásica para os fungos estudados a partir desses produtos agroindustriais selecionados proporcionou elevada produção de conídios em curto intervalo de tempo, podendo ser implantada em escala industrial.

\section{REFERENCES}

Agudelo, F. and Falcon, L.A. (1977), Some naturally occurring insect pathogens in Colombia. Turrialba, 27, 423-424.

Agudelo, F. and Falcon, L.A. (1983), Mass production, infectivity, and field application studies with the entomogenous fungus Paecilomyces farinosus. Journal of Invertebrate Pathology, 42,124-132.

Alvarenga, A.R.M.; Cruz, B.P.B.; Bulisani, E. A.; Oliveira, D. A.; Silveira, A. P. (1988), Novos testes de cultivo de fungos utilizados em controle biológico usando meios de cultura naturais líquidos. $O$ Biológico, 55, 31-35.

Alves, S.B.; Almeida, J.E.M.; Moino Junior, A.; Alves, L.F.A. (1998), Técnicas de laboratório. In-Controle Microbiano de Insetos, ed. S.B. Alves. Piracicaba, SP: FEALQ, pp. 637-711.

Alves, S.B. and Pereira, R.M. (1998), Produção de fungos entomopatogênicos. In-Controle Microbiano de Insetos, ed. S.B. Alves. Piracicaba, SP: FEALQ, pp. 845-869.

Alves, S.B. and Pereira, R.M. (1989), Produção do Metarhizium anisopliae (Metsch.) Sorok e Beauveria bassiana (Bals.) Vuill em bandejas. Ecossistema, 4, 188-192.

Batista Filho, A.; Cruz, B.P.B.; Camargo, L.M.P.C.A. and Oliveira, D.A. (1985), Crescimento de Beauveria sp., isolado de bicudo do algodoeiro (Anthonomus grandis Boheman), em meios de cultura naturais, líquidos. O Biológico, 51, 17-21.

Cliquet, S. and Jackson, M.A. (1999), Influence of culture conditions on production and freeze-drying tolerance of Paecilomyces fumosoroseus blastospores. Journal of Industrial Microbiology and Biotechnology, 23, 97-102.

Cruz, B.P.B.; Abreu, O.C.; Oliveira, A.D. and Chiba, S. (1993), Crescimento de Metarhizium anisopliae (Metsch.) Sorokin em meios de cultura naturais líquidos. O Biológico, 49, 111-116.

Faria, M.R. and Magalhães B.P. (2001), O uso de fungos entomopatogênicos no Brasil. Biotecnologia, Ciência e Desenvolvimento, 22, 18-21.

Humphreys, A.M.; Matewele, P.; Cunliffe, B. and Trinci, A.P.J. (1990), Comparison of sporulation of Paecilomyces farinosus and Beauveria bassiana in batch and fed-batch culture. Mycological Research, 94, 1046-1050.
Jackson, M.A.; Cliquet, S.; Iten, L.B. (2003), Media and fermentation process for the rapid production of high concentrations of stable blastospores of the bioinsecticidal fungus Paecilomyces fumosoroseus. Biocontrol Science and Technology, 13, 23-33.

Jackson, M.A. (1997), Optimizing nutritional conditions for the liquid culture production of effective fungal biological control agent. Journal of Industrial Microbiology and Biotechnology, 19, 180187.

Jenkins, N.E.; Heviefo, G.; Langewald, J.; Cherry, A.J. and Lomer, C.J. (1998), Development of mass production technology for aerial conidia for use as mycopesticides. Biocontrol News and Information, 19, 21-31.

Leite, L.C.; Batista Filho, A.; Almeida, J.E.M. and Alves, S.B. (2003), Produção de fungos entomopatogênicos. Ribeirão Preto, Brazil,

Rayati, D.J.; Aryantha, I.N.P. and Arbianto, P. (2001), The optimization of nutrient factors in spore production of Paecilomyces fumosoroseus (Wize) Brown and Smith with submerged-surface fermentation system. Paper presented at $50^{\text {th }}$ Symposium of Agri-Bioche, 11 March, Tokyo, Japan.

Rombach, M.C. (1988), Production of Beauveria bassiana (Deuteromycotina: Hyphomycetes) sympoduloconidia in submerged culture. Entomophaga, 34, 45-52.

Santa, H.S.D.; Santa, O.R.D.; Brand, D.; Vandenberghe, L.P. de S. and Soccol, C.R. (2005), Spore production of Beauveria bassiana from agroindustrial residues. Brazilian Archives of Biology and Technology, 48, 51-61.

SAS Institute Inc. (2001), Cary, North Carolina, USA.

Tanzini, M.R. (2002), Controle do percevejo-de-rendada-seringueira (Leptopharsa heveae) com fungos entomopatogênicos. PhD Thesis, University of São Paulo, Piracicaba, Brazil.

Torre, M. de la and Cardenas-Cota, H.M. (1996), Production of Paecilomyces fumosoroseus conidia in submerged culture. Entomophaga, 41, 443-453.

Zimmermann, G. (2008), The entomopathogenic fungi Isaria farinosa (formerly Paecilomyces farinosus) and the Isaria fumosorosea species complex (formerly Paecilomyces fumosoroseus): biology, ecology and use in biological control. Biocontrol Science and Technology, 18(9), 865-901.

Received: July 28, 2008; Revised: October 31, 2008; Accepted: November 09, 2009. 